\section{Edukatif Gerakan Sholat terhadap Daya Ingat Anak Tunagrahita Ringan}

\section{Fina Rahmayati Ishlahiyah, M. Shodiq A. M}

Universitas Negeri Malang

E-mail: rahmayatifina2@omail con

bstrak: Tujuan dari penelitian ini adalah untuk mengetahui pengaruh sebelum dan sesudah pemberian plikasi edukatif gerakan sholat terhadap daya ingat anak tunagrahita ringan. Penelitian ini menggunakan ancangan penelitian Pre-Exsperimental Design dengan desain "One Group Pretest-Posttest Design" Hasil analisis data ditemukan bahwa nilai rata-rata pre-test tes kinerja 52 , sedangkan tes tulis 50 , dan nilai ata-rata post-lest tes kinerja 84 , sedangkan tes tulis 88 . Hasil perhitungan Uji Wilcoxon diperoleh bahwa $H_{i} H_{i}$ diterima dan $H_{0} H_{o}$ ditolak, sebab $T_{\text {hitung }}(0) T_{\text {hitung }}(0) \leq T_{\text {tabel }(1)} T_{\text {tabel }}(\mathbf{1})$. Berdasarkan hasil tersebut disimpulkan bahwa media aplikasi edukatif memberikan pengaruh yang signifikan terhadap kemampuan daya ingat anak tunagrahita ringan.

Kata kunci: aplikasi edukatif, daya ingat gerakan sholat, tunagrahita ringan

Abstract: This study aims to determine the effect of before and after giving of 'sholat' movement thes Pre-Experimental Design research design with "One Group Pretest-Postest Desen" design. The results of the data analysis found that the average value of pre-test performance test 52 , while the written test 50 , and the average value of post-test performance test 84, while the written test

88. Wilcoxon test result obtained that $H_{i} H_{i}$ is accepted and $H_{0} H_{o}$ is rejected, because $T_{\text {hitung }}(0)$ $T_{\text {hitrung }}(0) \leq T_{\text {tabel (1) }} T_{\text {tabel (1) }}$. Based on these results it can be concluded that the educational media educative aplication gives a significant effect on the memory ability of towards memory recognition for Kegnen wh

Dalam upaya meningkatkan kemajuan di bidang pendidikan, segala upaya yang dilakukan pemerintah serta guru untuk membantu dan memajukan anak utama pada anak berkebutuhan khusus. Anak berkebutuhan khusus merupakan anak yang

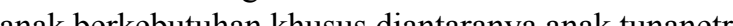
ank tunarungu anak thegrita, ank tumits, ak tunaras. Peneliti memilih salh solu berkebutuhan khusus yakni anak tunagrahita.

Menurut Somantri (2012) kecerdasan yang dimiliki anak tunagrahita di bawah rata-rata ditanda olen keterbatasan intelckual dan ketidakcakapa lam

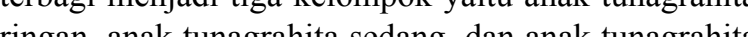
berat. Menurt Anak tumagraits memiliki IQ 68-52 berat. Menn

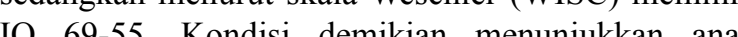
tunagrahita memiliki kognitif yang rendah.

Menurut Desmita (2012) perkembangan kognitif merupakan satu aspek perkembangan pada diri sisw yang berhubungan dengan pengetahuan. Perkembanga kognitif anak terjadi pada setiap fase seringkali gaga diselesaikan dalam melakukan transfer persepsi verba lemah dalam mengingat, baik itu mengingat jangka
Tabel 1 Rekapitulasi Nilai Pre-test Dan Post-test Pada Tes Kinerja

\begin{tabular}{llll}
\hline No & Nama & $\begin{array}{l}\text { Nilai } \\
\text { Pre-Test }\end{array}$ & $\begin{array}{l}\text { Nilai } \\
\text { Post-Test }\end{array}$ \\
\hline 1. & AM & 50 & 81 \\
2. & BN & 60 & 90 \\
3. & DW & 60 & 90 \\
4. & GG & 50 & 90 \\
5. & RN & 40 & 69 \\
\hline Jumlah & 260 & 420 \\
\hline \multicolumn{2}{l}{ Rata-rata } & 52 & 84
\end{tabular}

abel 2 Rekapitulasi Nilai Pre-test Dan Post-test Pada Tes Tulis

\begin{tabular}{llll}
\hline No & Nama & $\begin{array}{l}\text { Nilai } \\
\text { Pre-Test }\end{array}$ & $\begin{array}{l}\text { Nilai } \\
\text { Post-Test }\end{array}$ \\
\hline 1. & AM & 40 & 90 \\
2. & BN & 60 & 90 \\
3. & DW & 60 & 90 \\
4. & GG & 50 & 90 \\
5. & RN & 40 & 80 \\
\hline Jumlah & 250 & 440 \\
\hline \multicolumn{2}{l}{ Rata-rata } & 50 & 88
\end{tabular}

Menurut Hanko (2013) bahwa upaya meningkatkan daya ingat gerakan sholat anak tunagrahita ringan daya ingat gerakan sholat anak tunagrahita ringan satunya pengsunam media pembelajaran yang menarik dan edukatif bagi an. Media kreatif tersebut dengan menggunakan aplikasi edukatif Aplikasi edukatif yaitu suatu fitur permainan yang menyerupai tablet. Aplikasi edukatif ini cocok untuk anak tunagrahita ringan karen aplikasi edukatif ini menggunakan musik, gerakan uara, dan keheningan dalam beragam bentuk aktivita sebagai rangsangan daya ingat anak.

Konsep dalam aplikasi edukatif adalah suatu fitur permainan yang digunakan oleh guru dalam pembelajaran untuk meningkatkan kemampuan erakan sholat pada anak tunagrahita ringan. Penggunaan aplikasi edukatif ini sangat bermanfaat, selain menarik dalam proses pembelajarannya yang secara multisensori yaitu memanfaatkan indera pendengaran dan indera penglihatan. Aplikasi di dalamnya tercantum materi yang dapat diajarkan kepada anak, anak tidak mudah bosan pada proses pembelajaran. Melalui penggunaan media in diharapkan siswa mampu mengingat urutan gerakan holat dalam mempratikkannya dengan benar.

Seperti halnya dalam penelitian Aris Wahyudi (2014) didapatkan kesimpulan bahwa penggunaan media video animasi dapat meningkatkan kemampuan gerakan sholat pada mata pelajaran agama islam mater gerakan sholat di SDLB Bhakti Wiyata Surabaya.

Penelitian ini bertujuan untuk mengetahui pengaruh sebelum dan sesudah pemberian aplikasi edukatif gerakan sholat terhadap daya ingat anak tunagrahita ringan.

\section{METODE}

Penelitian ini menggunakan rancangan penelitian Pre-Eksperimental Design dengan desain "One Group treatment $3 \mathrm{kali}$, post-test $1 \mathrm{kali}$. Hal ini bertujuan untuk mengetahui adanya pengaruh sebelum dan sesudah pemberian aplikasi edukatif gerakan sholat terhadap daya ingat anak tunagrahita ringan kelas IV di SDLBN Kedungkandang Malang.

Subyek penelitian ini yaitu siswa kelas IV di SDLBN Kedungkandang Malang yang terdiri dari 5 SDLBN Kedungka
orang siswa putra.

Instrumen penelitian ini yaitu pemberian tes kepada subyek penelitian. Ada dua jenis pelaksanaan tes yang diberikan guna memperoleh data yang dianalisis yaitu pre-test dan post-test. Bentuk tes yang diberikan berupa tes kinerja dan tes tulis. Soal tes kinerja dan tes this yang digunakan pada pre-test dan post-lest memilliki materi yang sama. Tes kinerja wajib sholat secara langsung tes tulis berupacaan

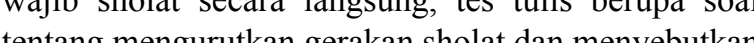
tentang mengurutkan gerak.
urutan bacaan wajib sholat.

Tujuan uji validasi untuk memperoleh kelayakan instrumen pengumpulan data. Uji validasi yang dilakukan adalah validator instrumen yang meliputi (ahli media, ahli pembelajaran, ahli materi), dan validasi isi berbentuk butir soal yang dilakukan dengan mengkonsultasikannya kepada ahli tersebut.

Data yang diperoleh dianalisis menggunakan statistik non-prametrik. Uji hipotesisnya menggunakan uji Wilcoxon. Adapun uji hipotesisnya dilakukan secara manual.

\section{HASIL DAN PEMBAHASAN}

\section{Hasil}

Hipotesis penelitian ini mengatakan bahwa terdapat pengaruh yang signifikan pemberian aplikasi edukatif gerakan sholat terhadap daya ingat anak tunagrahita ringan kelas IV di SDLBN Kedungkandang Malang. Berikut ini adalah rekapitulasi nilai pre-test dan post-test siswa.

Berdasarkan tabel 1,2 dan gambar 1,2 terlihat bahwa terdapat peningkatan nilai pre-test dan post-test. Dari sini terlihat bahwa sebelum diberikan perlakuan menggunakan media aplikasi edukatif nilai siswa lebih rendah dibandingkan sesudah diberikan perlakuan. Berdasarkan analisis data dengan menggunakan uji Wilcoxon secara manual diperoleh data Tabel 3 
Tabel 3 Analisis Data Uji Wilcoxon Tes Kinerja

\begin{tabular}{|c|c|c|c|c|c|c|}
\hline \multirow[b]{2}{*}{ No } & \multicolumn{2}{|l|}{ Nilai } & \multirow[b]{2}{*}{$(\mathrm{Y}-\mathrm{X})$} & \multirow[b]{2}{*}{ Rank } & \multicolumn{2}{|c|}{ Tanda } \\
\hline & $\begin{array}{l}\text { Pre- } \\
\text { test } \\
\text { (X) }\end{array}$ & $\begin{array}{l}\text { Post- } \\
\text { test } \\
\text { (Y) }\end{array}$ & & & Positif & Negatif \\
\hline 1 & 50 & 81 & 31 & 4 & 4 & 0 \\
\hline 2 & 60 & 90 & 30 & 2,5 & $+2,5$ & 0 \\
\hline 3 & 60 & 90 & 30 & 2,5 & $+2,5$ & 0 \\
\hline 4 & 50 & 90 & 40 & 5 & +5 & 0 \\
\hline 5 & 40 & 69 & 29 & 1 & +1 & 0 \\
\hline \multirow{2}{*}{\multicolumn{3}{|c|}{ Jumlah }} & & & & $T_{\text {hitung }}$ \\
\hline & & & & & $\mathrm{T}=15$ & $\begin{array}{l}T_{\text {hitumg }} \\
=\mathbf{0}\end{array}$ \\
\hline
\end{tabular}

Tabel 4 Analisis Data Uji Wilcoxon Tes Tulis

\begin{tabular}{|c|c|c|c|c|c|c|}
\hline \multirow[b]{2}{*}{ No } & \multicolumn{2}{|c|}{ Nilai } & \multirow[b]{2}{*}{ (Y-X) } & \multirow[b]{2}{*}{ Rank } & \multicolumn{2}{|c|}{ Tanda } \\
\hline & $\begin{array}{l}\text { Pre- } \\
\text { test } \\
\text { (X) }\end{array}$ & $\begin{array}{c}\text { Post- } \\
\text { test } \\
\text { (Y) }\end{array}$ & & & Positif & Negatif \\
\hline 1 & 50 & 90 & 40 & 4 & +4 & 0 \\
\hline 2 & 60 & 90 & 30 & 1,5 & $+1,5$ & 0 \\
\hline 3 & 60 & 90 & 30 & 1,5 & $+1,5$ & 0 \\
\hline 4 & 50 & 90 & 40 & 4 & +4 & 0 \\
\hline 5 & 40 & 80 & 40 & 4 & +4 & 0 \\
\hline
\end{tabular}

Jumlah

$\mathbf{T}=\mathbf{1 5} \stackrel{T_{\text {hitrung }}}{T_{\text {hiturg }}}$

Berdasarkan tabel 4 hasil da $\boldsymbol{T}_{\text {.......... }} \boldsymbol{T}_{\text {: }}$ tulis diperoleh nilai T kecil yaitu $T_{\text {hitung }} T_{\text {hitung }}=$

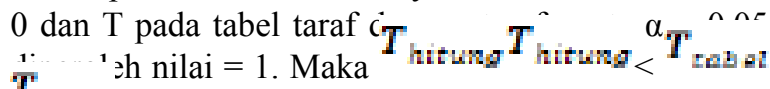
$T_{\text {tas at }}$ sehingga $0<1$

Hal ini menunjukkan bahwa penggunaan media aplikasi edukatif gerakan sholat berpengaruh terhad daya ingat anak tunagrahita ringan kelas IV di SDLBN Kedungkandang Malang.

\section{Pembahasan}

Hasil penelitian menunjukkan bahwa gerakan sholat berpengaruh terhadap daya ingat anak tunagrahita ringan kelas IV di SDLBN Kedungkandan Malang. Hal ini dilihat dari hasil pre-test dan post-test siswa yang seluruh siswa mengalami peningkatan pad nilai tes kinerja maupun tes tulis. Pemilihan tes sesua dengan pendapat somantri (2012) bahwa karakteristik anak tunagrahita ringan yaitu anak memilik kecerdasan di bawah rata-rata IQ 55-69, anak tidak mash bis bejar mogat secara sederhana. Maka dari itu, media aplikas edukatif ini dapat membantu anak tunagrahita ringa dalam mengingat urutan gerakan sholat dan menghafa bacaan wajib sholat dengan benar.

Dengan media aplikasi edukatif anak tunagrahita ringan dapat mengingat urutan gerakan sholat dan menghafal bacaan wajib sholat dengan cara meneka tombol dari salah satu gambar urutan gerakan shola sesuai intruksi guru dengan benar. Dalam pembelajara siswa sangat antusias dan mampu menjawa pertanyaan sesuai intruksi guru dengan benar. Sisw juga mampu mempratikkan gerakan sholat secara uru dan benar mulai dari gerakan takbiratul ikhram sampai salam dengan menggunakan media aplikasi edukati secara berkelanjutan, maka siswa akan hafal denga sendirinya baik itu menghafal urutan gerakan shola dan bacaan wajib sholat. Sholat itu wajib dikerjaka setiap muslim, seiring pendapat Achmadi, dkk. (2009) sholat merupakan ibadah yang wajib bagi setia muslim, jika sholat dikerjakan sesuai rukunnya maka kan mendapatkan pahala, jika dikerjakan tidak sesuai rukunnya maka sholatnya tidak sah.

Berdasarkan hasil analisis data terdapat perbedaa yang signifikan pemberian media aplikasi edukatif gerakan sholat terhadap daya ingat anak tunagrahit ringan kelas IV di SDLBN Kedungkandang Malans. Perbedaan nilai rata-rata pre-test sangat renda dibandingkan dengan nilai rata-rata post-test. Artiny setelah pembelajaran menggunakan media aplika edukatif terjadi peningkatan. Amy, dkk. (2010) memo adalah suatu proses penyimpanan dan pengeluara kembali informasi yang didapat dari proses belajar. Seiring pendapat Kurniasih (2013) daya ingat peser didik didapat melalui pengalaman yang diterima ketika kegiatan pembelajaran berlangsung yang diolah dalam otak untuk disimpan kemudian mengungka kembali informasi tersebut. Jadi memori merupaka keakuratan otak dalam mengingat pelajaran, baik itu mengingat undan gerakan sholat dan menghaf caan wajib sholat dalam tes kinerja maupun tes tulis.

Perbedaan rata-rata nilai pre-test dan post-test karena adanya penggunaan media aplikasi edukatif pad proses pemberian treatment. Treatment menggunaka media ini menjadikan siswa lebih antusias dalan belajar terutama belajar materi urutan gerakan shola dan bacaan wajib sholat. Media ini membantu daya ingat siswa untuk mengingat materi pelajaran denga mudah. Ditambah media ini cara menggunakanny cukup ditekan salah satu gambar gerakan sholat sesuai intruksi guru.

Seiring pendapat Hanko (2013) bahwa upaya meningkatkan daya ingat gerakan sholat anak tunagrahita ringan diperlukan strategi dan kreaktivita tinggi, salah satunya penggunaan media pembelajar yang menarik dan edukatif bagi anak. Media kreatif kan aplikasi edukatif Aplikasi edukatif yaitu suatu fitur permainan yang menyerupai tablet. Aplikasi edukatif ini cocok untuk anak tunagrahita ringan karena aplikasi edukatif in menggunakan musik, gerakan, suara, dan keheningan dalam beragam bentuk aktivitas sebagai rangsangan daya ingat anak.

Dengan menggunakan media aplikasi edukatif dalam pembelajaran dapat mencapai tujuan yaitu meningkatnya daya ingat anak tunagrahita ringan kelas IV di SDLBN Kedungkandang Malang pada materi pembelajaran urutan gerakan sholat dan bacaan wajib sholat, media aplikasi edukatif ini sangatlah ringan dan dapat dibawa kemana-mana, jadi siswa tidak harus belajar di dalam ruang kelas saja.

\section{KESIMPULAN DAN SARAN}

\section{Kesimpulan}

Berdasarkan penelitian ini, dapat disimpulkan daya ingat anak tunagrahita ringan kelas IV di SDLBN Kedungkandang Malang pada kategori kurang. Hal ini diketahui dari hasil perolehan nilai rata-rata pretest tes kinerja 52 , tes tulis 50 sebelum treatment menggunakan aplikasi edukatif. Sedangkan daya ingat anak tunagrahita ringan kelas IV di SDLBN Kedungkandang Malang pada kategori sangat baik. Hal ini diketahui dari hasil perolehan nilai rata - rata post-test tes kinerja 84 , tes tulis yang mengalam kenaikan 88. Dengan demikian, media aplikasi edukatif gerakan sholat berpengaruh terhadap daya ingat anak tunagrahita ringan kelas IV di SDLBN Kedungkandang Malang.

Saran

Berdasarkan hasil penelitian maka saran kepada (1) peneliti selanjutnya dapat melanjutkan penelitian dengan menggunakan aplikasi edukatif selain dalam
pembelajaran agama, tetapi dalam pembelajaran bahasa indonesia, bahasa inggris, dan matematika; (2) guru dalam proses pembelajarannya hendaknya menggunakan media aplikasi edukatif agar daya ingat anak dapat meningkat, (3) sekolah diharapkan ingat anak dapat meningkat, (3) sekolah diharapkan
lebih menyediakan media yang menarik dalam proses pembelajarannya untuk menunjang tecapainya tujuan pembelajaran.

\section{DAFTAR RUJUKAN}

Achmadi, dkk. (2009). Bina Fikih Untuk Madrasah Ibtidaivah Kelas II. Jakarta : Erlangga.
Amy, dkk. (2010). Pengaruh Kadar Glukosa Darah Terhadap Peningkatan Daya Ingat Jangka Pendek Pada Wanita Dewasa. Jurnal Kedokteran, (Online), 8 (1): 15, (http://portalgaruda.org/ article.php/Pengaruh-Kenaikan-Kadar-GlukosaDarah-terhadap-Peningkatan-Daya- IngatJangka-Pendek-pada-Wanita-Dewasa). Diakses 26 November 2016

Cahayanik, N. N. (2011). Bimbingan Anak-anak Bersholat. Surabaya : Karya Ilmu.

Desmita. (2012). Psikologi Perkembangan Peserta Didik. Bandung : PT Remaja Rosdakarya.

Hanko, J. (2013). Permainan Edukatif Untuk Anak Berkebutuhan Khusus. Jakarta : PT Bhuana Ilmu Populer.

Kurniasih, Y. (2013). Bimbingan Belajar Berbasis Konsep Mind Map Untuk Meningkatkan Daya Ingat Peserta Didik Underachiever. Bandung : Ingat Peserta Didik Underachiever. Bandung :
Perpustakaan Universitas Pendidikan Indonesia.

Somantri, T. S. (2012). Psikologi Anak Luar Biasa. Bandung : PT Refika Aditama.

Sugiyono. (2015). Metode Penelitian Pendidikan (Pendekatan Kuantitatif, Kualitatif, dan R\&D). Bandung : Alfabeta.

TIM Universitas Negeri Malang. (2010). Pedoman Penulisan Karya Ilmiah: Skripsi, Tesis, Disertasi, Penelitian, Edisi Keling. Malune, Livoran Peneli Mr Edisi Kelim

Wahyudi, A. (2014). Pengaruh Penggunaan Media Pembelajaran Video Animasi Terhadap Pelajaran Pendidikan Sholat Anak Autis Mata Pelajakan Shondidikan Agama Islam Materi Surabay Skripsi tidek diterbitkat SUrbat:

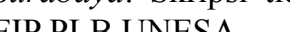
FIP PLB UNESA. 